\title{
Analisis Kritrik Strukturalis Cerpen Yabu No Naka Karya Akutagawa Ryunosuke
}

\author{
Moh Faizal Fuad Aziz \\ Universitas Pesantren Tinggi Darul U'lum Jombang \\ faizalfuadazis@fbs.unipdu.ac.id
}

\begin{abstract}
Abstrak
Analisis struktural digunakan oleh penulis dalam menganalisis cerpen Yabu no Naka dengan jalan memisahkan unsur-unsur pembentuk cerpen yaitu: tokoh dan penokohan, alur, latar dan pelataran, tema, dan amanat. Dialog-dialog yang dilakukan antar tokoh menyebabkan perwatakan masing-masing tokoh dapat terungkap lebih jelas. Pengaluran dalam cerpen Yabu no Naka menggunakan alur flashback (regresif) dan ada konflik yang terjadi yang berhubungan dengan tokoh utama dan tokoh tambahan serta ada hubungan kausalitas antara peristiwa yang satu dengan peristiwa yang lain. Latar utama dalam cerpen Yabu no Naka ini adalah Yamashina, sebuah kota di Prefektur Kyoto. Tema utama dalam cerpen Yabu no Naka ini adalah pembunuhan dan pembenaran.
\end{abstract}

Kata kunci: analisis struktural, regresif, alur

\begin{abstract}
Structural analysis is used by the writer in analyzing the short story of Yabu no Naka by separating the forming elements of short stories, namely: character and characterization, plot, background and court, theme, and date. Dialogues made between characters cause the character of each character can be revealed more clearly. The distribution in the short story of Yabu no Naka uses the flashback (regressive) flow and there is a conflict that occurs related to the main character and additional characters and there is a causal relationship between one event and another. The main setting in the short story of Yabu no Naka is Yamashina, a city in Kyoto Prefecture. The main theme in this short story of Yabu no Naka is murder and justification.
\end{abstract}

Keyword: structural analysis, regressive, plot

\section{PENDAHULUAN}

Sebuah karya sastra dalam hal ini cerpen, pada dasarnya merupakan bangunan struktur yang bermakna, yang unsur-unsurnya saling berjalin erat dan menentukan satu dengan yang lainnya. Unsur-unsur karya sastra seperti tokoh dan penokohan, alur, latar dan pelataran, tema dan amanat saling berkaitan dan mendukung satu dengan yang lain sehingga membangun kesatuan makna. Cerpen Yabu no Naka merupakan salah satu dari beberapa cerpen karya Akutagawa Ryunosuke. Pengarang besar yang lahir di Irifunechoo Kobayashi, Tokyo pada 1 Maret 1892 dan meninggal dunia pada 24 April 1927 dengan 
cara bunuh diri meminum obat tidur dengan dosis tinggi karena ia tidak mau menjadi gila. Selama hidupnya ia menghasilkan kira-kira 150 buah karya fiksi yang terdiri dari novel, cerpen, essai, catatan harian dan catatan pengalaman.

Setiap karya sastra memiliki elemen- elemen struktural yang meliputi tokoh (penokohan), alur, latar, tema, dan amanat. Tokoh adalah individu rekaan yang mengalami peristiwa atau perlakuan di dalam cerita (Sudjiman, 1988:16). Tokoh dan penokohan merupakan salah satu unsur pembentuk struktur karya sastra. Pembicaraan tokoh meliputi tokoh cerita, jenis tokoh, dan perwatakan, sedangkan pembicaraan tentang penokohan meliputi bagaimana penempatan dan pelukisan tokoh di dalam cerita.

Alur merupakan salah satu elemen struktural karya sastra. Alur adalah peristiwaperistiwa cerita yang mempunyai penekanan pada adanya hubungan kausatif. Alur berisi penampilan peristiwa-peristiwa yang tidak hanya berdasarkan urutan waktu saja tapi peristiwa-peristiwa itu berhubungan sebab-akibat. Alur tidak hanya mengungkapkan apa yang terjadi tetapi yang lebih penting adalah mengapa hal itu terjadi (Sudjiman, 1988:30).

Elemen structural karya sastra lainnya adalah latar, tema, dan amanat. Latar atau setting yang disebut juga landas tumpu menyaran pada pengertian tempat, waktu, dan lingkungan sosial tempat terjadinya peristiwa-peristiwa yang diceritakan (Abrams melalui Nurgiantoro, 1994:175). Tema adalah gagasan, ide atau pokok pikiran utama yang mendasari sebuah karya sastra (Sudjiman, 1988:50). Tema juga merupakan permasalahan utama yang ditampilkan pengarang. Dalam sebuah karya sastra bisa terdapat lebih dari satu permasalahan, tetapi dari beberapa permasalahan tersebut dapat ditarik benang merah yang disebut dengan tema utama.

Sedangkan amanat berarti pesan yang umum disampaikan pengarang kepada pembaca yang dapat berfungsi sebagai jalan keluar untuk pemecahan masalah yang terdapat dalam sebuah cerita. Amanat dapat ditemukan jika pembaca sudah memahami karya sastra tersebut secara keseluruhan (Sudjiman, 1988:57).

Tujuan dari penelitian ini adalah untuk mengetahui apa dan bagaimana tokoh dan penokohan, alur, latar dan pelataran, tema, serta amanat dalam cerpen Yabu no Naka. Selanjutnya berdasarkan analisis di atas penulis berusaha untuk mengetahui bagaimana hubungan antar unsur intrinsik dalam cerpen Yabu no Naka untuk membentuk suatu keutuhan cerita. 


\section{METODE PENELITIAN}

Metode yang digunakan dalam penelitian ini adalah metode struktural. Teeuw (1984:135) mengatakan bahwa analisis struktural bertujuan untuk memaparkan secara cermat, teliti, detail dan memiliki keterkaitan serta keterjalinan semua unsur aspek karya sastra sehingga dapat menghasilkan makna menyeluruh.

\section{PEMBAHASAN}

\section{A. Analisis Struktural Cerpen Yabu no Naka Karya Akutagawa Ryunosuke}

Cerpen Yabu no Naka bercerita tentang tujuh kesaksian dan pengakuan yang berbeda mengenai kasus pembunuhan seorang samurai, Kanazawa Takehiro. Jasadnya ditemukan di hutan bambu pinggiran kota Kyoto. Cerita Yabu no Naka bermula dengan empat kesaksian pendukung dari seorang penebang kayu, rahib Budha, agen polisi, dan wanita tua. Lalu menyusul kesaksian utama dari korban maupun pelaku pembunuhan, yaitu seorang bandit yang bernama Tajomaru, pengakuan Masago (istri dari suami yang terbunuh), hingga arwah Takehiro (seorang samurai) yang berbicara melalui perantara seorang dukun. Tokoh utama yang pertama dalam cerpen Yabu no Naka ini adalah Tajomaru. Pengarang menggambarkan tokoh Tajomaru sebagai seorang penjahat yang terkenal sadis.

何、男を殺すなぞは、あなた方の思っているように、大した事ではありません。どうせ 女を奪うとなれば、必ず、男は殺されるのです。唯私は殺す時に、腰の太刀を使う

のですが、あなた方は太刀は使わない。唯権力で殺す、金で殺す、どうかするとお 為ごかしの言葉 だけでも殺すでしよう。

Nani, otoko o korosunazo wa, anatagata no omotteiru youni, taishita kotodewa arimasen. Douse onna o ubau tonareba, kanarazu, otokowa korosarerunodesu. Tada watashi wa korosu tokini, koshi no tachi o tsukau no desu ga, anatagata wa tachi wa tsukawanai. Tada kenryoku de korosu, kane de korosu, douka suru to otamegokashi no kotoba dake demo korosu deshou.

「『藪の中』、2009:13ページ」

Apa? Seperti yang Anda bayangkan, membunuh laki-laki itu bukan perkara besar. Kalau mau merebut perempuan itu, kan suaminya harus dibunuh. Ketika membunuh, saya menggunakan pedang. Tetapi tidak begitu dengan Anda sekalian. Anda tidak menggunakan pedang untuk membunuh, cukup dengan kekuasaan, dengan uang, bahkan hanya dengan kata-kata mungkin Anda dapat membunuh.

(Yabu no Naka, 2009:13) 
Tokoh utama yang kedua dalam cerpen Yabu no Naka ini adalah Kanazawa Takehiro. Seorang samurai yang menjadi korban pembunuhan. Tokoh ini merupakan pusat pembicaraan dalam cerpen Yabu no Naka. Ia adalah suami dari Masago. Takehiro digambarkan sebagai tokoh yang telah mati, tetapi ia bersaksi melalui mulut Biksuni Kuil Shinto.

\section{巫女の口を借りたる死霊の物語 。}

Miko no kuchi o karitaru shiryou no monogatari.

「『藪の中』、2009:22ページ」

Kisah roh orang mati melalui mulut Biksuni.

(Yabu no Naka, 2009:22)

盗人にこう云われると、妻はうっとりと顔を擡げた。おれはまだあの時程、美しい 妻を見た事がない。しかしその美しい妻は、現在縛られたおれを前に、何と盗人 に返事をしたか？おれは中有に迷っていても、妻の返事を思い出す毎に、眞恚 に燃えなかったためしはない。妻は確かにこう云った、一「ではどこへでもつれて行 って下さい。」（長き沈黙）

Nusubito ni kouiwareru to, tsuma wa uttori to kao o motageta. Ore wa mada ano toki hodo, utsukushii tsuma o mita koto ga nai. Shikashi sono utsukushii tsuma wa, genzai shibarareta ore o maeni, nan to nusubito ni henji o shitaka? Ore wa chuu ni mayotteitemo, tsuma no henji o omoi dasu goto ni, shini ni moenakatta tameshi wa nai. Tsuma wa tashikani kouitta, —_dewa doko e demotsurete itte kudasai.] (nagaki chinmoku)

「『藪の中』、2009:23ページ」

Mendengar ucapan penyamun itu istri saya menengadahkan wajah seakan terpukau. Saya belum pernah melihat ia secantik itu. Tetapi, apa jawaban perempuan cantik itu kepada si penyamun di depan suaminya yang dalam keadaan terbelenggu? Meski tidak lagi hidup di dunia ini dan roh saya masih gentayangan, bagaimanapun juga saya tetap merasa marah dan dendam setiap kali teringat jawaban dia. - kalau begitu bawalah aku kemanapun kau pergill... Yang pasti, itulah jawaban dia. (lama terdiam).

(Yabu no Naka, 2009:23)

Tokoh utama yang ketiga dalam cerpen Yabu no Naka ini adalah Masago. Masago mempunyai ciri fisik yaitu wajahnya oval mungil dan sedikit gelap, serta terdapat tahi lalat di sudut mata sebelah kiri. Masago merupakan wanita yang tidak pernah dekat dengan lakilaki lain selain suaminya. Ia juga mempunyai karakter yang keras hati, tidak kalah dengan laki-laki. 
娘でございますか。娘の名は真砂、年は十九歳でございます。これは男にも劣ら ぬ位、勝気の女でございますが、まだ一度も武弘の外には、男を持った事はござ いません。顔は色の浅黒い、左の眼尻に黒子のある、小さい瓜実顔ででざいま す。

Musume de gozaimasuka? Musume no na wa Masago, toshi wa juukyuusai de gozaimasu. Kore wa otoko nimo otoranukurai, kachiki no onna de gozaimasuga, mada ichidomo Takehiro no hokani wa, otoko o motta koto wa gozaimasen. Kao wa iro no asaguroi, hidari no mejiri ni hokuro no aru, chiisai urizanegao de gozaimasu.

「『藪の中』、2009:11ページ」

Anak perempuan saya? Namanya Masago, usianya 19 tahun. Ia keras hati, tidak kalah dengan laki-laki. Ia sama sekali tidak pernah dekat dengan lakilaki lain selain Takehiro. Kulit wajahnya agak gelap, di sudut mata sebelah kiri terdapat tahi lalat, dan wajahnya mungil berbentuk oval.

(Yabu no Naka, 2009:11)

Berdasarkan urutan waktu, cerpen Yabu no Naka menggunakan alur flashback (regresif). Alur tersebut untuk menyelidiki kembali peristiwa pembunuhan secara mundur. Hal ini bisa dilihat dari isi cerpen yang berupa bagian-bagian dari kesaksian dan pengakuan yang dijelaskan tokoh-tokoh tentang peristiwa pembunuhan yang telah terjadi. Dilihat dari kutipan kesaksian dan pengakuan para tokoh, dalam cerpen Yabu no Naka ini pengarang menggunakan sudut pandang (point of view) akuan sertaan atau biasa disebut first person central. Cerita disampaikan oleh tokoh-tokoh. Karena cerita dilihat dari sudut pandangnya, maka cerita memakai kata ganti $a k u$.

わたしが搦め取った男でございますか？これは確かに多襄丸と云う、名高い盗 人でございます。

Watashi ga karame totta otoko de gozaimasuka? Kore wa tashikani Tajoumaru to iu, nadakai nusubito de gozaimasu.

「『數の中』、2009:9-10ページ」

Laki-laki yang saya tangkap? Kalau tidak salah ia bernama Tajomaru, seorang maling terkenal.

(Yabu no Naka, 2009:9-10)

Latar tempat terjadinya pembunuhan dalam cerpen ini adalah Yamashina, sebuah kota di Prefektur Kyoto. Pembunuhan terjadi di dalam belukar di sebuah lembah pegunungan. Tempat terjadinya pembunuhan inilah yang dijadikan pengarang sebagai 
judul cerpen. Yabu no Naka yang berarti di dalam belukar, dimaksudkan dapat mewakili inti dalam cerpen tersebut bahwa konflik cerita terjadi di dalam belukar.

すると山陰の藪の中に、あの死骸があったのでございます。あった処でございます

か？それは山科の駅路からは、四五町 ほど隔たっておりましょう。竹の中に瘦せ 杉の交った、人気のない処でございます。

Suru to yamakage no yabu no naka ni, ano shigai ga attanode gozaimasu. Atta tokoro de gozaimasuka? Sore wa Yamashina no ekiro kara wa, shigochou hodo hedatatte orimashou. Take no naka ni yasesugi no majitta, hitokenonai tokoro de gozaimasu.

「『藪の中』、2009:7ページ」

Mayat itu berada di dalam belukar di lembah pegunungan itu. Lokasi ditemukannya? Kira-kira 500 meter dari jalan di Yamashina. Di hutan bambu bercampur pohon sugi kurus, tempat yang jarang dilalui oleh manusia.

(Yabu no Naka, 2009:7)

Latar waktu dalam cerpen ini tergambar pada waktu penceritaan. Bisa diperkirakan latar waktu dalam cerpen ini yaitu pada Era Heian. Hal ini dapat dilihat dari adanya penjelasan suikan (水干) dalam isi cerita. Suikan merupakan pakaian yang umumnya dikenakan orang-orang biasa (bukan kaum bangsawan) pada Era Heian. Setelah Era Kamakura, suikan jarang dipakai kecuali dalam ritual atau oleh orang yang berjabatan tertentu. Selain suikan, bukti yang menunjukkan bahwa waktu penceritaan dalam cerpen pada Era Heian yaitu adanya kebiishi (検非違使). Kebishii adalah jabatan yang berfungsi hingga akhir Era Heian.

わたしが搦め取った男でございますか？これは確かに多襄丸と云う、名高い盗 人でございます。尤もわたしが搦め取った時 には、馬から落ちたのでございましよ う、粟田口の石橋の上に、うんうん呻っておりました。時刻ででざいますか？時刻 は昨夜の初更頃でございます。いつぞやわたしが捉え損じた時にも、やはりこの 紺の水干に、打出しの太刀を佩いておりました。ただ今はそのほかにも御覧の 通り、弓矢の類さえ携えております。さようでございますか？あの死骸の男が持つ ていたのも、——では人殺しを働いたのは、この多襄丸に違いございません。革 を巻いた弓、黒塗りの箙、鷹の羽の征矢が十七本、一一これは皆、持っていた ものででざいましょう。 
Watashi ga karame totta otoko de gozaimasuka? Kore wa tashikani Tajoumaru to iu, nadakai nusubito de gozaimasu. Mottomo watashi ga karame totta toki ni wa, uma kara ochita node gozaimashou, Awataguchi no ishibashi no ue ni, un un unatte orimashita. Jikoku de gozaimasuka? Jikoku wa sakuya no shokougoro de gozaimasu. Itsu zoya watashi ga torae sonjita toki ni mo, yahari kono kon no suikan ni, uchidashi no tachi o haite orimashita. Tadaima wa sono hokani mo goran no toori, yumiya no taguisae tazusaete orimasu. Sayou de gozaimasuka? Ano shigai no otoko ga motte ita nomo, - dewa hitogoroshi o hatara ita no wa, kono Tajoumaru ni chigai gozaimasen. Kawa o maita yumi, kuronuri no ebira, taka no hane no soya ga juunanahon, - kore wa mina, motte ita mono de gozaimashou.

「『藪の中』、2009:9-10ページ」

Laki-laki yang saya tangkap? Kalau tidak salah ia bernama Tajomaru, seorang maling terkenal. Ketika saya tangkap ia sudah terjatuh dari kudanya. Ia mengerang kesakitan di atas jembatan batu di Awataguchi. Waktu kejadiannya? Kemarin malam, sekitar jam delapan. Saat saya hendak menangkapnya beberapa waktu lalu ia juga mengenakan suikan biru tua dan menyandang sebilah pedang. Seperti yang sekarang Anda ketahui, ia juga membawa sebangsa busur dan anak panah. Benarkah seperti itu? Yang membawa mayat lelaki itu, dan yang membunuhnya pastilah Tajomaru. Busur yang dibungkus kulit, tempat anak panah yang dipernis hitam, 17 batang anak panah dengan hiasan bulu sayap burung elang, — saya kira semuanya milik lelaki itu.

(Yabu no Naka, 2009:9-10)

検非違使に問われたる木樵りの物語 。

Kebiishi ni towaretaru kikori no monogatari.

「『藪の中』、2009:7ページ」

Kisah kesaksian penebang kayu di hadapan penyidik.

(Yabu no Naka, 2009:7)

Latar sosial dalam cerpen ini mengenai perilaku kehidupan masyarakat. Pada budaya orang Jepang, terlebih zaman dahulu, budaya malu sangat diutamakan dalam kehidupan. Seperti yang dilakukan Tajomaru ketika ingin merebut Masago dari Takehiro. Ia tidak langsung membunuh Takehiro kemudian membawa lari Masago. Tetapi ia mengajak Takehiro untuk bertarung dengan pedang. Ia malu jika membunuh Takehiro tanpa bertarung dahulu.

しかし男を殺すにしても、卑怯な殺し方はしたくありません。私は男の縄を解いた 上、太刀打ちをしろといいました。（杉の根がたに落ちていたのは、その時捨て 
忘れた縄なのです。）男は血相を変えたまま、太い太刀を引き抜くました。と思 うと口も利かずに、憤然と私へ飛びかかりました。

Shikashi otoko o korosu ni shitemo, hikyouna koroshikata wa shitake arimasen. Watashi wa otoko no nawa o to ita ue, tachiuchi o shiroto iimashita. (sugi no negate ni ochite itanowa, sono toki sute wasureta nawana no desu). Otoko wa kesso o kaetemama, futoi tachi o hikinukumashita. To omouto kuchi mo kikazuni, funzen to watashi e tobikakarimashita.

「『藪の中』、2009:13ページ」

Tetapi kalaupun memutuskan untuk membunuhnya, saya tidak ingin dengan cara pengecut. Setelah melepas ikatannya saya mengajaknya bertarung menggunakan pedang. (Tali yang tercecer pada akar pohon sugi adalah tali yang waktu itu lupa saya buang). Laki-laki itu menghunus pedangnya yang besar dengan raut muka murka. Tanpa mengeluarkan sepatah kata pun secepat kilat dengan sangat marah ia menerjang saya.

(Yabu no Naka, 2009:13)

Pelataran yang digunakan pengarang dalam cerpen Yabu no Naka ini yaitu pelataran sejalan. Pengarang menampilkan latar sesuai dengan keadaan tokoh dan keadaan lingkungan. Dua keadaan tersebut tidak kontras.

わたしは藪の前へ来ると、宝はこの中に埋めてある、見に来てくれといいました。 男は慾に渇いていますから、異存のあるはずはありません。が、女は馬も下りずに、待っ ているというのです。またあの藪の茂っているのを見ては、そういうのも無理はありますまい。 私はこれも実をいえば、思う盇にはまったのですから、女一人を残したまま、男と藪の中 ヘはいりました。

Watashi wa yabu no mae e kuru to, takara wa kono naka ni uzumete aru, mini kite kure to iimashita. Otoko wa yoku ni kawaite imasukara, izon no aru hazu wa arimasen. Ga, onna wa uma mo orizuni, matteiru to iu no desu. Mata ano yabu no shigette iru no o mite wa, sou iu no mo muri wa arimasumai. Watashi wa kore mo jitsu o ieba, omou tsubo ni wa matta no desu kara, onna hitori o nokoshitamama, otoko to yabu no naka e hairimashita.

$$
\text { 「『數の中』、2009:14ページ」 }
$$

Sampai di dekat belukar itu saya katakan bahwa benda-benda berharga itu dipendam di tengah belukar, dan saya meminta mereka untuk ikut melihatnya. Karena laki-laki itu diselimuti ketamakan, ia tidak keberatan sama sekali. Tetapi tanpa turun dari kudanya, perempuan itu mengatakan akan menunggu saja. Melihat rimbunnya belukar, wajar kalau ia mengatakan hal itu. Kalau bicara jujur 
sebenarnya rencana saya berjalan sesuai harapan, kami masuk ke dalam belukar dengan meninggalkan perempuan itu sendirian.

(Yabu no Naka, 2009:14)

Tema yang terdapat dalam cerpen Yabu no Naka adalah tentang pembunuhan dan pembenaran. Tema pembunuhan dalam cerpen ini dapat dilihat dari cerita yang berisi tentang penyelidikan kasus pembunuhan yang melibatkan beberapa kesaksian dan pengakuan dari tokoh-tokoh. Adapun tema pembenaran dapat dilihat dari tujuh kesaksian yang berbeda menegenai kasus pembunuhan. Setiap tokoh menceritakan kisah yang mereka alami ketika melihat peristiwa pembunuhan. Semua kesaksian berbeda-beda ceritanya. Meskipun tidak bisa diketahui siapa yang benar dan siapa yang berbohong, semua tokoh memberikan kesaksian dengan pembenaran bahwa kesaksiannya lah yang paling benar. Pembenaran inilah yang menjadi tema sentral dalam cerpen Yabu no Naka.

Dari isi cerita Yabu no Naka, dapat dipetik amanat atau pesan moral bahwa manusia dalam kehidupan sehari-hari seringkali melihat pembenaran sebagai suatu kebenaran melalui perspektifnya masing-masing. Di samping itu, manusia sangat sulit untuk mengutarakan kebenaran yang sesungguhnya. Yang ada hanyalah pembenaran. Mereka seringkali beranggapan bahwa pendapatnya adalah yang paling benar diantara pendapatpendapat yang lain.

Tokoh dalam cerpen Yabu no Naka memiliki hubungan dengan alur cerita. Kesaksian dan pengakuan para tokoh dalam cerpen ini sangat berperan dalam menentukan alur cerita. Setiap tokoh menceritakan kesaksian dan pengakuan tentang peristiwa pembunuhan yang telah terjadi. Peristiwa pembunuhan yang terjadi merupakan kejadian masa lalu, sedangkan cerita kesaksian dan pengakuan setiap tokoh merupakan masa sekarang. Jadi dalam cerpen ini kronologi pembunuhan diceritakan secara mundur. Penokohan tokoh utama juga sangat tepat dengan latar sosial dalam cerpen ini. Latar sosial menggambarkan tentang perilaku atau kebiasaan masyarakat. Pada budaya orang Jepang, budaya malu merupakan hal yang sangat diutamakan dalam kehidupan. Seperti yang dilakukan Tajomaru ketika ingin merebut Masago dari Takehiro. Ia tidak langsung membunuh Takehiro kemudian membawa lari Masago. Tetapi ia mengajak Takehiro untuk bertarung dengan pedang. Ia malu jika membunuh Takehiro tanpa bertarung dahulu. Selanjutnya adalah hubungan antara tema dan amanat. Tema dalam cerpen ini sangat berkaitan dalam menemukan amanat. Tema tentang pembenaran dalam cerpen ini merupakan amanat atau pesan moral yang ingin disampaikan oleh pengarang bahwa manusia dalam kehidupan sehari-hari 
seringkali melihat pembenaran sebagai suatu kebenaran melalui perspektifnya masingmasing.

\section{KESIMPULAN}

Analisis struktural digunakan oleh penulis dalam menganalisis cerpen Yabu no Naka dengan jalan memisahkan unsur-unsur pembentuk cerpen yaitu: tokoh dan penokohan, alur, latar dan pelataran, tema, dan amanat. Setelah unsur-unsur tersebut dianalisis satu per satu didapat adanya keterkaitan di antara unsur-unsur pembentuk cerpen tersebut.

a. Perwatakan tokoh-tokoh dalam cerpen Yabu no Naka ada yang hanya digambarkan dalam satu sisi saja yaitu sisi baik atau disebut dengan perwatakan datar dan ada yang digambarkan dari berbagai sisi atau perwatakan bulat. Dialog-dialog yang dilakukan antar tokoh menyebabkan perwatakan masing-masing tokoh dapat terungkap lebih jelas.

b. Pengaluran dalam cerpen Yabu no Naka menggunakan alur flashback (regresif) dan ada konflik yang terjadi yang berhubungan dengan tokoh utama dan tokoh tambahan serta ada hubungan kausalitas antara peristiwa yang satu dengan peristiwa yang lain. Di sini terlihat adanya keterkaitan antara alur dan penokohan.

c. Latar utama dalam cerpen Yabu no Naka ini adalah Yamashina, sebuah kota di Prefektur Kyoto. Pembunuhan terjadi di dalam belukar di sebuah lembah pegunungan. Sedangkan latar waktu dalam cerpen Yabu no Naka ini diperkirakan pada Era Heian. Hal ini dapat dilihat dari adanya penjelasan suikan（水干） dalam isi cerita. Selain itu adanya adanya kebiishi（検非違使）, yaitu jabatan yang berfungsi hingga akhir Era Heian. Latar sosial dalam cerpen ini mengenai perilaku kehidupan masyarakat yang juga memiliki hubungan erat dengan tokoh utama.

d. Tema utama dalam cerpen Yabu no Naka ini adalah pembunuhan dan pembenaran. Kemudian tema dan amanat juga saling memiliki hubungan yang erat. Tema tentang pembenaran dalam cerpen ini merupakan amanat atau pesan moral yang ingin disampaikan oleh pengarang bahwa manusia dalam kehidupan sehari-hari seringkali melihat pembenaran sebagai suatu kebenaran melalui perspektifnya masing-masing. 
Dengan demikian, dapat ditarik kesimpulan bahwa terdapat keterkaitan antara unsurunsur pembentuk cerpen yang didapat dengan cara menguraikan dan menyatukan kembali unsur-unsur tersebut sehingga secara bersama dapat membentuk makna yang utuh.

\section{REFERENSI}

Nurgiyantoro, Burhan. 1994. Teori Pengkajian Fiksi. Yogyakarta: Gadjah Mada UniversityPress.

Ryunosuke, Akutagawa. 2009. Yabu No Naka. Japan: Tokuma Bunko.

Sudjiman, Panuti. 1988. Memahami Cerita Rekaan. Jakarta: Pustaka Jaya.

Teeuw, A. 1984. Sastra dan Ilmu Sastra: Pengantar Teori Sastra. Jakarta: Pustaka Jaya. 